\title{
Effect of host size on virulence of Taura Virus to the marine shrimp Penaeus vannamei (Crustacea: Penaeidae)
}

\author{
Jeffrey M. Lotz* \\ Gulf Coast Research Laboratory, Institute of Marine Sciences, University of Southern Mississippi, PO Box 7000 , \\ Ocean Springs, Mississippi 39566-7000, USA
}

\begin{abstract}
Taura Disease (Taura Syndrome), caused by Taura Virus (Taura Syndrome Virus), is the most important disease of the farmed penaeid shrimp Penaeus vannamei in the Western Hemisphere One possible tactic to offset Taura Virus-induced mortalities is for culturists to use larger shrimp for stocking ponds. This study consisted of 4 experiments designed to test the hypothesis that $P$. vannamei becomes more tolerant of Taura Virus infections as it becomes larger. Experiments were done in either $100 \mathrm{l}$ glass aquaria or $4000 \mathrm{l}$ cylindrical fiberglass tanks. All shrimp used in experiments were SpecificPathogen-Free Penaeus vannamei derived from the United States Marine Shrimp Farming Program Population 1. The Taura Virus in all experiments originated from infected farm-reared shrimp collected during a 1995 Taura Virus outbreak in Texas, USA. Experimental shrimp were inoculated with virus either per os by allowing shrimp to feed on triturated infected shrimp tissue or intramuscularly by injection of a cell-free suspension of infected shrimp tissue into the abdominal musculature. In the 4 experiments 9 to $14 \mathrm{~d}$ survival ranged from 0 to nearly $60 \%$. Analysis of each of the 4 experiments by logistic regression revealed a consistent trend for larger shrimp to be more likely to succumb to infection; however, the effect was only statistically significant in 2 of the 4 experiments. The results of the experiments failed to support the hypothesis that $P$. vannamei increases its tolerance to Taura Virus as it increases in size from 1 to $30 \mathrm{~g}$
\end{abstract}

KEY WORDS: Taura Virus · TSV · Host-size effects - Penaeus vannamei Shrimp disease · Route of exposure - Disease resistance

\section{INTRODUCTION}

Taura Virus (TV) causes the most important disease of farmed penaeid shrimp in the Western Hemisphere and annual production losses are estimated to be greater than U.S. $\$ 100000000$ (Brock et al. 1995, Lightner et al. 1995). The disease was first observed in Ecuador in 1992, but its cause remained unknown until Brock and his colleagues demonstrated that a virus (probably belonging to the Picornaviridae) causes a histological lesion that is pathognomonic for Taura Syndrome (TS) (Brock et al. 1995, Hasson et al. 1995). The word 'syndrome' refers to the suite of signs characterizing a disease that is often of unknown etiology. Since TS is now known to be caused by a viral agent

•E-mail: jlotz@seahorse.ims.usm.edu and its presence is diagnosed by a single sign (histological lesion), it may be more appropriate to refer to the disease as Taura Disease and the agent as Taura Virus.

Taura Virus has now been identified in most shrimp farming regions of the Americas (Lightner 1996). In Penaeus vannamei Taura Virus causes a rapidly progressing disease marked by extensive mortalities that become evident 25 to $35 \mathrm{~d}$ after a shrimp pond is stocked with shrimp. Elevated death rates last only a matter of days but commonly reach $25 \%$ per day and leave a mere 5 to $25 \%$ of the shrimp alive. Taura Virus is a particularly virulent pathogen of $P$. vannamei, the most commonly cultured shrimp in the Americas (Brock et al. 1995, Hasson et al. 1995, Overstreet et al. 1997). However, Brock et al. (1995) found Taura Virus to be less virulent to $P$. stylirostris and Overstreet et al. 
(1997) found it to be less pathogenic to $P$. setiferus. Overstreet et al. (1997) found that Taura Virus can infect $P$. aztecus and $P$. duorarum, although they found little evidence of pathogenicity.

Taura Virus is now established in many countries of Central and South America and outbreaks have been confirmed in Mexico and the United States. Evidence also exists that Taura Virus has been introduced into natural populations of Penaeus vannamei in Central America, Mexico, Ecuador, and probably elsewhere (Lightner 1996).

Farmers are searching for strategies that might offset Iosses from the Taura Virus pandemic. In the United States the approach has been to employ SpecificPathogen-Free shrimp and increase biosecurity measures to prevent further introductions of the virus (Lotz et al. 1995, Lotz in press). In regions where the virus is already established, such methods may not be applicable and management strategies must be employed that are effective in the presence of the virus. Among possible (although not tested) compensatory tactics are overstocking, adjusting alkalinity and $\mathrm{pH}$ of pond water, and nursing animals to larger sizes in biosecure systems before stocking.

Use of a protected nursery phase was deemed worthy of investigation because animals often become more resistant to a particular pathogen as they reach larger size. Increased resistance with increased size (age) has been demonstrated for the shrimp viral pathogens Infectious Hypodermal and Hematopoietic Necrosis Virus (IHHNV) (Bell \& Lightner 1987) and Baculovirus penaei (BP) (LeBlanc \& Overstreet 1990). Overstreet et al. (1997) present evidence that larger Penaeus setiferus are less susceptible to mortality from Taura Virus than smaller $P$. setiferus. However, they were not able to show that Taura Virus virulence in $P$. vannamei between $<0.1$ and $5 \mathrm{~g}$ depended on size of the shrimp. In the study reported herein, the work of Overstreet et al. (1997) was extended to include $P$. vannamei between sizes 4 and $30 \mathrm{~g}$. Two questions were asked: (1) Does resistance to Taura Virus increase as size of $P$. vannamei increases? and (2) Does resistance to Taura Virus actually decrease as size of P. vannamei increases?

\section{MATERIALS AND METHODS}

Experiments were performed in either $100 \mathrm{l}$ glass aquaria (bottom, $30 \mathrm{~cm}$ by $90 \mathrm{~cm}$; height, $38 \mathrm{~cm}$ ) or $4000 \mathrm{l}$ cylindrical fiberglass tanks $(2.5 \mathrm{~m}$ in diameter by $0.9 \mathrm{~m}$ high). Aquaria were housed in a restrictedaccess isolation room and tanks were housed in a restricted access isolation greenhouse. Both isolation units were equipped with a footbath containing an iodophore disinfectant (Wescodyne ${ }^{\text {(B) }}$ ) at the entrance. Each $100 \mathrm{l}$ aquarium contained about $95 \mathrm{l}$ of seawater at a salinity of $15 \mathrm{ppt}$ and was equipped with a small submerged biological filter and an air supply. Each tank contained about $2000 \mathrm{l}$ of seawater at a salinity of 15 ppt and was equipped with a trickling biological filter and an air supply. Temperatures were between 25 and $28^{\circ} \mathrm{C}$.

Seawater used in experiments was natural estuarine water from Davis Bayou, Ocean Springs, Mississippi, USA. Natural water was settled, disinfected with chlorine bleach, and the salinity was adjusted upward to 15 ppt by adding a commercial artificial sea salt (Forty Fathoms ${ }^{\circledR}$ Bio-crystals). No water was exchanged during any of the experiments. At the end of each experiment surviving shrimp were placed in Davidson's Alcohol-Formalin-Acetic Acid (AFA) fixative (Bell \& Lightner 1988) for possible histological examination and the water was disinfected in situ with chlorine bleach. Disinfected water was discharged into a holding tank where it was treated a second time with chlorine bleach. Eventually the waste water was discharged into the municipal sewage system of Ocean Springs, Mississippi, USA.

All shrimp used in experiments were Specific Pathogen Free (SPF) Penaeus vannamei derived from United States Marine Shrimp Farming Program (USMSFP) Population 1. The history of these animals was outlined by Wyban et al. (1992). Briefly, Population 1 entered the USMSFP's SPF program from a commercial hatchery in Sinaloa, Mexico in 1989. It has been housed in a secure facility on the island of Hawaii, Hawaii, USA, after undergoing extensive quarantine and meeting the International Council for the Exploration of the Sea (ICES) guidelines for introduction of exotic species (Sindermann 1990). Lotz et al. (1995) list the pathogens from which this population is free. During experiments, animals were maintained on $40 \%$ protein commercial shrimp grower pellets (Rangen ${ }^{(2)}$ ) ad libitum.

The Taura Virus for this study originated from infected farm-reared USMSFP Population 1 Penaeus vannamei collected during a 1995 TV outbreak in Texas, USA. The infectious material has been maintained at the Gulf Coast Research Laboratory (GCRL) in SPF population 1 Penaeus vannamei since that time. We have found no histopathological evidence at either the light or transmission electron microscopical level of any other agents in our viral stock throughout numerous experimental exposures. Experimental shrimp were exposed to virus either per os by allowing shrimp to feed on triturated infected shrimp tissue or intramuscularly by injection of a cell-free aqueous extract of infected shrimp tissue into the abdominal musculature. For per os exposures, exoskeleton-free shrimp 
cephalothoraces were chopped finely. Animals exposed by feeding were fed at the rate of $7.5 \%$ of body weight The cell-free viral suspension was prepared by initially triturating exoskeleton-free, infected cephalothoraces in an equal volume of distilled water with a kitchen blender. The resulting material was further ground in a tissue homogenizer. The homogenized suspension was passed through a nitrocellulose membrane filter (pore size $0.45 \mu \mathrm{m}$ ). The filtrate was diluted 1:10 and the viral preparation was inoculated into abdominal shrimp muscle at the rate of $0.02 \mathrm{ml} \mathrm{g}^{-1}$ shrimp wet weight. Shrimp used for negative controls were exposed either per os or by injection of material that was prepared exactly as above except that uninfected shrimp tissues were substituted for infected shrimp tissues. For each experiment in this study a different lot of infectious material was used. Each lot was produced from experimental mass exposures that were induced by feeding infected tissue at the rate of $7.5 \%$ body weight to at least $200 \mathrm{P}$. vannamei in a $1000 \mathrm{l}$ tank. A lot was prepared by pooling at least 50 to 100 (usually more) cephalothoraces of moribund or freshly dead shrimp collected during the days of highest mortalities following mass exposure (typically Day 3 to Day 7). Only one lot of infectious material was prepared for each experiment.

During each experiment all dead and moribund animals were fixed in AFA and some were used to verify the presence of diagnostic Taura Virus lesions histologically. Following fixation, shrimp were embedded in paraffin, sectioned at $5 \mu \mathrm{m}$ thickness, and stained with hematoxylin followed by eosin counterstain (H\&E staining). The endpoint for the experiments was survival and in 3 of the 4 studies only enough shrimp were examined histologically to confirm that TV lesions were present in the experimental unit. In these 3 experiments usually only 1 animal was needed from each tank or aquarium but in some cases as many as 5 were examined. Histological examination consisted of a thorough microscopical inspection of 2 non-serial sections of the cephalothorax of each shrimp analyzed.

Survival was recorded in each experiment after elevated death rates subsided in the experimental units. This usually occurred 5 to $8 \mathrm{~d}$ post exposure. Survival data were analyzed by logistic regression (Hosmer \& Lemeshow 1989) using S-PLUS ${ }^{\circledR}$ software (StatSci, Inc.). Logistic regression is derived from a generalization of linear regression and analysis of variance as developed by Nelder \& Wedderburn (1972). It is the appropriate analysis when the response variable is dichotomous, e.g. present/absent, dead/alive, and the predictor variable is categorical (including dichotomous), ordinal, or continuous. Alpha was set to 0.05 .

The study consisted of 4 separate experimental exposures performed at 4 separate times.
Expt 1. Expt 1 was executed in ten 100 l aquaria. Three sizes of shrimp were used: 7,14 and $19 \mathrm{~g}$. Two of the aquaria contained $7-g$ shrimp $(9$ individuals each), 4 contained 14 -g shrimp $(6,4,9$, and 16 individuals), and 4 contained $19-\mathrm{g}$ shrimp $(5,6,6$, and 7 individuals). All shrimp were inoculated with Taura Virus intramuscularly. Survival was recorded $9 \mathrm{~d}$ after exposure. All dead and moribund shrimp collected on Days 2 to 8 of the experiment were examined histologically for presence of Taura Virus lesions. Animals of each size class were maintained in separate tanks and served as negative controls.

Expt 2. Expt 2 was performed in four $100 \mathrm{l}$ aquaria. Two of the aquaria contained 202 -g shrimp each, and 2 contained $1512 \mathrm{~g}$ shrimp each. Animals in one aquarium of each size shrimp were inoculated with Taura Virus intramuscularly and the animals in the second aquarium were inoculated per os. Final survival was recorded $14 \mathrm{~d}$ after exposure. A replicate set of tanks matching animal size and exposure route was used as the negative control.

Expt 3 . Expt 3 was done in a single 4000 l tank. The tank contained $3004-g$ shrimp, $8814 \mathrm{~g}$ shrimp, and $8822-g$ shrimp. Animals were exposed to Taura Virus by placing an aliquot of inoculum equal to $7.5 \%$ of total shrimp biomass into the tank. Survival was recorded $14 \mathrm{~d}$ after exposure. A replicate $4000 \mathrm{l}$ tank containing a matched set of animals was used as a negative control.

Expt 4. Expt 4 was carried out in two $4000 \mathrm{l}$ tanks. Each tank contained 75 5-g shrimp, 2014 -g shrimp, and $1530-g$ shrimp. Animals were exposed to Taura Virus per os. To ensure that each size class was exposed to an inoculum equal to $7.5 \%$ of its own body weight, animals were segregated by size within each tank. Animals of the 2 small size classes were placed into $45 \mathrm{l}$ cylindrical in-tank mesh baskets $140 \mathrm{~cm}$ diameter by $35 \mathrm{~cm}$ high). The baskets had solid bottoms to prevent loss of inoculum during exposure. One day after exposure, shrimp were released from the exposure baskets and the 3 size classes were allowed to freely mix in the tank. Final survival was recorded $14 \mathrm{~d}$ after exposure. A single tank containing a matched set of animals was used as a negative control.

\section{RESULTS}

\section{Expt 1}

Animals in Expt 1 were exposed to Taura Virus by injection. As the size of the experimental animals increased, a smaller proportion of animals survived to Day 9. On Day 9 post exposure, 8 of $187 \mathrm{~g}$ shrimp, 9 of $3514-\mathrm{g}$ shrimp and 3 of $2419-\mathrm{g}$ shrimp had survived. 
Fig. 1 displays the proportion surviving and the 95\% confidence intervals for shrimp in each size class. The negative relationship in Taura Virus-exposed animals between size and the proportion that survived was confirmed by logistic regression analysis. The logistic regression coefficient of -0.14 was significantly different from 0 .

In this experiment all dead and dying shrimp were examined histologically. The presence of Taura Virus infections was confirmed; however, lesions were observed only on Days 4 to 6 (15/20 animals had Taura Virus lesions). No lesions were observed before Day 4 (0/12 had Taura Virus lesions) nor after Day 6 (0/8 had Taura Virus lesions). No lesions were detected in any of 11 animals that survived to Day 9 .

No mortality was observed in any of the size classes of the negative control animals.

\section{Expl 2}

Animals in Expt 2 were exposed to Taura Virus by either injection or by feeding. On Day 14 post exposure, shrimp exposed by injection had lower survivals than shrimp exposed by feeding. Within each exposure group larger animals had lower survivals. Three of 20 2-g shrimp and 0 of $1512-g$ shrimp survived injection exposure and 12 of $202-g$ shrimp and 8 of 15 12-g shrimp survived feeding exposure. Fig. 2 displays the proportion surviving with $95 \%$ confidence intervals for shrimp in the 4 experimental groups. Logistic regression detected a significant regression

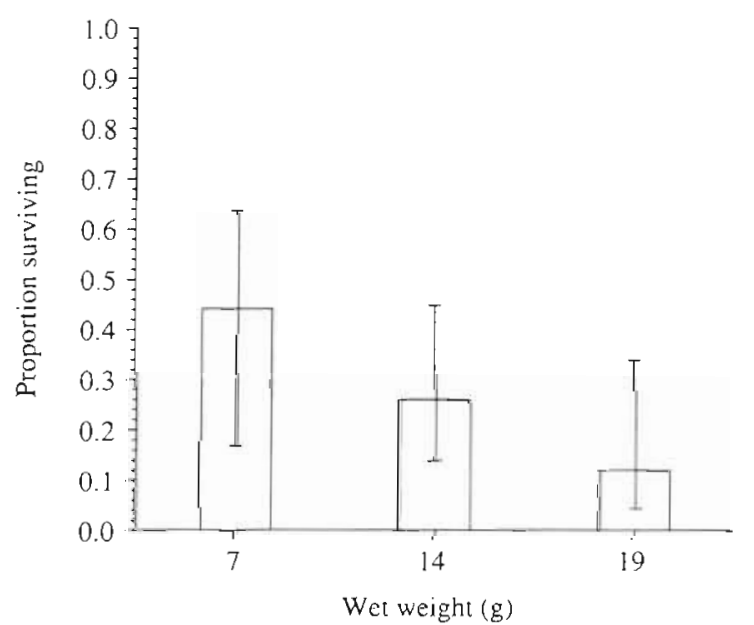

Fig. 1. Penaeus vannamei. Survival at $9 \mathrm{~d}$ of 3 size classes exposed to Taura Virus by ingestion in Expt 1. Vertical lines are $95 \%$ confidence intervals. The logistic regression coefficient for the effect of shrimp size was -0.14 ( $p=0.02$; Wilks' likelihood ratio chi-squared test). The odds ratio, which measures how much more likely an animal is to die from a Taura Virus exposure as size increases, was 0.87

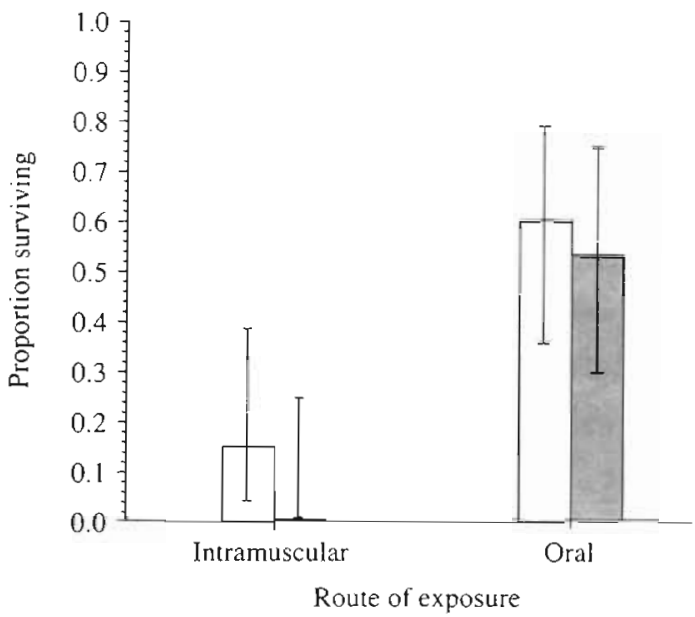

Fig. 2. Penaeus vannamei Survival at $14 \mathrm{~d}$ of 2 size classes exposed to Taura Virus by injection and ingestion in Expt 2. Unshaded bars refer to $2 \mathrm{~g}$ shrimp and shaded bars refer to $12 \mathrm{~g}$ shrimp. Vertical lines are $95 \%$ confidence intervals. The logistic regression coefficient for the effect of route of exposure was 1.35 ( $\mathrm{p}<0.00001$; Wilks' likelihood ratio chi-squared test) and the odds ratio (a measure of how much more likely an animal is to die from a Taura Virus exposure by injection than by ingestion) was 3.86 . The logistic regression coefficient and odds ratio for the effect of shrimp size was $-0.068(p=0.26$; Wilks' likelihood ratio chi-squared test) and 0.93 respectively

coefficient (1.35) for an effect of the route of exposure on surviving a Taura Virus infection. As in Expt 1 the logistic regression coefficient for size effects was negative $(-0.068)$; however, unlike Expt 1 the coefficient for size was not significantly different from 0 .

Histological examination of a sample of dead or dying shrimp from each exposed aquarium confirmed the presence of Taura Virus infections.

No mortality was observed in any of the size classes of the negative control animals.

\section{Expt 3}

Animals in Expt 3 were exposed to Taura Virus together in a single $4000 \mathrm{l}$ tank by feeding. On Day 14 post exposure 39 of $3004 \mathrm{~g}$ shrimp, 12 of $8814 \mathrm{gg}$ shrimp, and 10 of 8822 -g shrimp had survived Taura Virus infections. Fig. 3 displays the proportion surviving with $95 \%$ confidence intervals for shrimp in each size class. No relationship between survival and size was evident. Although the logistic regression coefficient for size was negative $(-0.006)$, it was not significantly different from 0 .

Histological examination of from 1 to 3 dead and dying shrimp from each exposed tank confirmed the presence of Taura Virus infections in the those units.

No shrimp mortality was observed in any of the size classes of the negative control tank. 


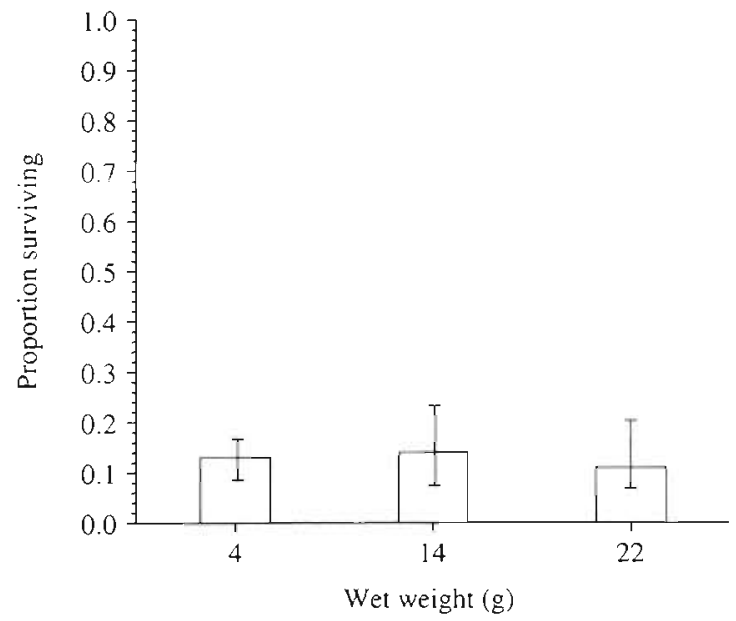

Fig. 3. Penaeus vannamei. Survival at $14 \mathrm{~d}$ of 3 size classes exposed to Taura Virus by ingestion in Expt 3. Vertical lines are $95 \%$ confidence intervals. The logistic regression coefficient for the effect of shrimp size was -0.006 ( $p=0.76$; Wilks' likelihood ratio chi-squared test). The odds ratio, which measures how much more likely an animal is to die from a Taura Virus exposure as shrimp size increases, was 0.99

\section{Expt 4}

Although animals of each size class in Expt 4 were maintained together in two $4000 \mathrm{l}$ tanks, they were exposed to Taura Virus separately by feeding. On Day 14 post exposure 87 of $1505 \mathrm{~g}$ shrimp, 18 of $4014 \mathrm{gg}$ shrimp, and 2 of $3030 \mathrm{~g}$ shrimp survived. Fig. 4 displays the proportion surviving with $95 \%$ confidence intervals for shrimp in each size class. A negative rela-

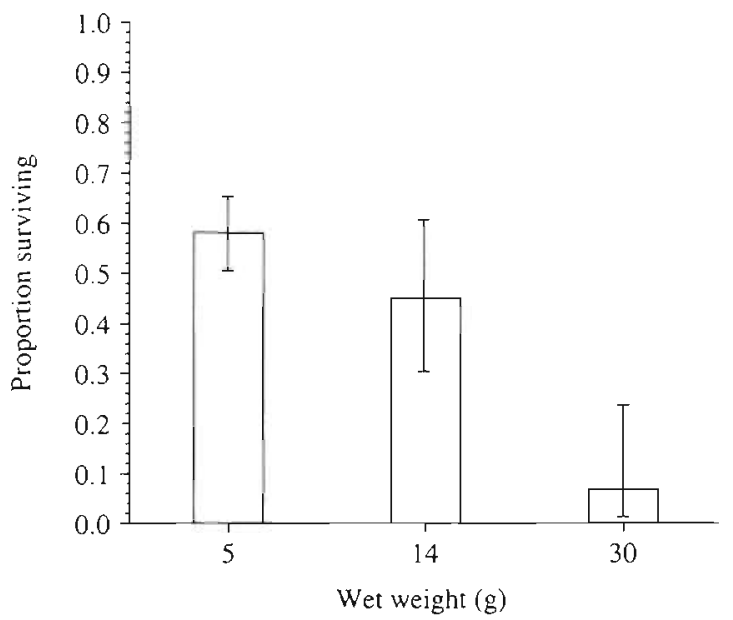

Fig. 4. Penaeus vannamei. Survival at $14 \mathrm{~d}$ of 3 size classes exposed to Taura Virus by ingestion in Expt 4 . Vertical lines are $95 \%$ confidence intervals. The logistic regression coefficient for the effect of shrimp size was -0.10 ( $p<0.00001$; Wilks' likelihood ratio chi-squared test). The odds ratio, which measures how much more likely an animal is to die from a

Taura Virus exposure as shrimp size increases, was 0.90 tionship between size and the proportion of shrimp that survive a Taura Virus exposure was confirmed by logistic regression analysis. The logistic regression coefficient of -0.10 was significantly different from 0 . Histological examination of a sample of 1 to 5 dead and dying from each exposed tank confirmed the presence of Taura Virus infections in each of the exposed tanks.

No shrimp mortality was observed in any of the size classes of the negative control tanks.

\section{DISCUSSION}

Answers to 2 questions were sought by this study: (1) Does resistance to Taura Virus increase as the size of $P$. vannamei increases? and (2) Does resistance to Taura Virus actually decrease as the size of $P$. vannamei increases? The data clearly answer the first question negatively and strongly reject the hypothesis that there is an increase in resistance with an increase in the size of $P$. vannamei. This conclusion agrees with the data of Overstreet et al. (1997) that showed no increase in resistance to Taura Virus infections as $P$. vannamei increased in size. However, the 4 experiments extend the conclusion from the range of $<0.1-5 \mathrm{~g}$ to a range of $2 \mathrm{~g}$ juveniles to $30 \mathrm{~g}$ adults.

The answer to the second question is not as clear because, although all 4 experiments produced negative logistic regression coefficients between Taura Virus induced mortality and shrimp size, statistically significant coefficients were observed in only 2 of them (Expts 1 and 4). Further, it should be pointed out that the $30 \mathrm{~g}$ shrimp used in Expt 4 had been in maturation for about 3 mo prior to exposure to Taura Virus. Most of those animals were males but some ablated females were also included. It is therefore likely that the largest size class may have been weakened by the stresses due to maturation and reproduction.

Expt 1 ran for only $9 d$ whereas the other 3 were not terminated until Day 14. However, in all experiments elevated mortalities had subsided by Days 5 to 7 and it is unlikely that an additional $5 \mathrm{~d}$ would have modified the conclusion.

Expts 2 and 3 produced coefficients that were negative but they were not statistically significant. However, Expt 3 may have failed to show a stronger negative coefficient because the 3 size classes of shrimp were exposed together at the rate of $7.5 \%$ of total body weight. Smaller shrimp typically have greater feeding rates than larger shrimp and in aquaculture the amount of food as a percentage of body weight is usually adjusted downward during a growout cycle (Villalon 1991, Wyban \& Sweeney 1991). Therefore in Expt 3 smaller shrimp may have received a higher dose per $g$ of body weight than larger animals. In the other 
3 experiments doses of Taura Virus were adjusted so that all animals received the same dose per $g$ of body weight.

It is clear that there is no increased resistance to Taura Virus by Penaeus vannamei as size of the shrimp increases and that Taura Virus infections in adult animals are at least as virulent and possibly more virulent than in smaller animals. These results argue against the use of larger animals in aquaculture to offset Taura Virus virulence and point out the importance of dose in any assessment of susceptibility. A casual observation in an aquaculture setting that larger animals appear less susceptible to a particular pathogen than smaller animals should be interpreted carefully. The appearance of increased resistance with increased size might be obtained if the likelihood of mortality from a Taura Virus exposure depended upon the initial dose. The reasoning follows. Shrimp can acquire Taura Virus infections in 1 of 2 ways, by ingestion of virus in infected tissue or contaminated water or by absorption of virus directly from the water through the general body surface or gills. For both the ingestion and absorption modes of transmission the dose of Taura Virus per $g$ of shrimp will decrease as shrimp size increases. As pointed out previously, feeding rate of $P$. vannamei decreases as size increases. Therefore large shrimp ingest less food per $g$ of body weight than small shrimp and small animals might receive a larger dose of virus per $g$ of body weight than larger animals. Similarly, if shrimp acquire Taura Virus infections passively by absorption from the water through the body surface, then the amount of virus accumulated per $g$ of body weight would be related to the surface area:body weight ratio. This ratio decreases as an animal increases in size. Gill pumping rate probably also decreases as body size increases since animals typically have a lower metabolic rate at larger sizes than they do at smaller sizes. If infection arises from any of these routes, large animals would receive a smaller per $\mathrm{g}$ dose of virus than small animals. Following these arguments there could be the appearance of increased resistance with size not because larger animals were innately more resistant but because they gained a smaller initial viral dose per $g$ of body weight.

The occurrence of Taura lesions in animals during the course of infection was monitored during Expt 1. The Taura lesions were observed only on Days 4 to 6 of the $9 \mathrm{~d}$ experiment. This suggests that Taura lesions occur only over a portion of the infection interval and that diagnosis of Taura Virus by histological examination is not always possible. This result concurs with that of Brock et al. (1995) and Overstreet et al. (1997). Only 2 non-serial sections were examined from each shrimp so it is possible that lesions would have been found in more shrimp if more sections of each shrimp had been examined. However, we have found in other studies that Taura Virus-exposed shrimp lacking histological Taura Virus lesions induced mortalities and Taura Virus lesions in susceptible indicator shrimp when indicator shrimp were fed unfixed tissue.

Expt 2 demonstrated that shrimp mortality from Taura Virus exposure was higher by injection than ingestion. However, it is difficult to compare accurately these results because it is not yet feasible to measure the number of Taura Virus virions present in challenge doses. In spite of this limitation, it can be concluded that injection results in more virulent infections. Specifically, shrimp exposed by feeding were given infectious material equal to $7.5 \%$ of their body weight, whereas those exposed by injection received $0.02 \mathrm{ml}$ of a 1:10 dilution of cell-free tissue extracts. The extraction procedure produced a final extract that was a 1:20 dilution of shrimp tissue $(1 \mathrm{~g}$ of shrimp extracted in $1 \mathrm{ml}$ of water and diluted by $1: 10$ ). Hence, $0.02 \mathrm{ml}$ of injected extract represented $0.001 \mathrm{~g}$ of shrimp tissue or a dose of $0.1 \%$ by body weight. Further it is unlikely that the extraction was complete for all of the virus particles in the tissue. Thus the injection dose was a smaller dose than that from feeding $17.5 \%$ of body weight). These arguments support the contention that injection resulted in more virulent infections than did oral exposure. The lower virulence per os may be partly attributed to some protection provided by the stomach and digestive tract against Taura Virus infections.

Acknowledgements. I acknowledge the able assistance of Verlee Breeland, Mike Turner, and Chad Seymour in implementing the experiments and Leslie Christmas for histological expertise. The research was supported by USDA CSREES through grants no. 92-38808-6920 and no. 96-38808-2580.

\section{LITERATURE CITED}

Bell TA, Lightner DV (1987) IHHN disease of Penaeus stylirostris: effects of shrimp size on disease expression. J Fish Dis 10:165-170

Bell TA, Lightner DV (1988) A handbook of normal penaeid shrimp histology. World Aquaculture Society. Baton Rouge, LA

Brock JA, Gose R, Lightner DV, Hasson KW (1995) An overview on Taura syndrome, an important disease of farmed P. vannamei. In: Browdy CL, Hopkins JS (eds) Swimming through troubled waters. Proceedings of the Special Session on Shrimp Farming. The World Aquaculture Society, Baton Rouge, LA, p 84-94

Hasson KW, Lightner DV, Poulos BT, Redman RM, White BL, Brock JA, Bonami JR (1995) Taura syndrome in Penaeus vannamej: demonstration of a viral etiology. Dis Aquat Org 23:115-126

Hosmer DW, Lemeshow S (1989) Applied logistic regression. John Wiley \& Sons, Inc, New York 
LeBlanc BD, Overstreet RM (1990) Prevalence of Baculovirus penaei in experimentally infected white shrimp (Penaeus vannamei) relative to age. Aquaculture 87:237-242

Lightner DV (1996) A handbook of shrimp pathology and diagnostic procedures for diseases of cultured penaeid shrimp. World Aquaculture Society, Baton Rouge, LA

Lightner DV, Redman RM, Hasson KW, Pantoja CR (1995) Taura syndrome in Penaeus vannamei (Crustacea: Decapoda): gross signs, histopathology and ultrastructure. Dis Aquat Org 21:53-59

Lotz JM (in press) Disease control and pathogen status assurance in an SPF-based shrimp aquaculture industry, with particular reference to the United States. In: Flegel $T$, MacRae IH (eds) Diseases in Asian aquaculture III. Asian Fisheries Society, Manila

Lotz JM, Browdy CL, Carr WH, Frelier PF, Lightner DV (1995) USMSFP suggested procedures and guidelines for assuring the specific pathogen status of shrimp broodstock and seed. In: Browdy CL, Hopkins JS (eds) Swimming through troubled waters. Proceedings of the Special Session on Shrimp Farming. World Aquaculture Society, Baton Rouge, LA, p 66-75

Responsible Subject Editor: J. E. Stewart, Dartmouth, Nova Scotia, Canada
Nelder J, Wedderburn RWM (1972) Generalized linear models. J Roy Stat Soc A135:370-384

Overstreet RM, Lightner DV, Hasson KW. Mcllwain S, Lotz JM (1997) Susceptibility to TSV of some penaeid shrimps native to the Gulf of Mexico and Southeastern US. J Invertebr Pathol 69:165-176

Sindermann CJ (1990) Principal diseases of marine fish and shellfish, Vol 2, 2nd edn. Academic Press, Inc, San Diego, $\mathrm{CA}$

Villalon JR (1991) Practical manual for semi-intensive commercial production of marine shrimp. Texas A \& M University Sea Grant Program, Galveston, TX, TAMU-SG91-501

Wyban JA, Sweeney JN (1991) Intensive shrimp production technology. The Oceanic Institute shrimp manual. The Oceanic Institute, Honolulu, HI

Wyban JA, Swingle JS, Sweeney JN, Pruder GD (1992) Development and commercial performance of high health shrimp using specific pathogen free (SPF) broodstock Penaeus vannamei. In: Wyban JA (ed) Proceedings of the Special Session on Shrimp Farming. World Aquaculture Society, Baton Rouge, LA, p 254-260

Manuscript received: November 12, 1996 Revised version accepted: March 17, 1997 